\title{
Communication
}

\section{Theoretical Insights from Binding of Neigleria fowleri Cell Division Proteins with Amoebicidal Quassinoids}

\author{
Zarrin Basharat *1, Shumaila Zaib², Azra Yasmin² \\ ${ }^{1}$ Jamil-ur-Rahman center for Genome Research, Dr. Panjwani Centre for Molecular Medicine and Drug \\ Research, International Center for Chemical and Biological Sciences, University of Karachi-75270, Karachi, \\ Pakistan. \\ ${ }^{2}$ Microbiology \& Biotechnology Research Lab, Department of Environmental Sciences, Fatima Jinnah Women \\ University, Rawalpindi 46000, Pakistan. \\ * Correspondence: zarrin.iiui@gmail.com
}

\begin{abstract}
The ameboflagellate Neigleria fowleri, also known as brain eating amoeba is responsible for fatal primary amoebic meningoencephalitis (PAM) infection in humans. Cell division proteins (CDPs) in N. fowleri have been uncharacterized until now, despite their importance in the initiation of cell division and proliferation of the pathogen. Here, we report characterization and structural assembly of eight such proteins associated with division and docking them with anti-amoebic quassinoid compounds. Quassinoids have been implicated as inhibitors of cell proliferation of amoeboid species as well as tumor cells. Here, they were screened computationally to find interaction mechanism as well as binding energies with CDPs of $N$. fowleri. The identified inhibitors could play a role in prevention of cell division and hence, stop $N$. fowleri growth and proliferation during infection. This study supports CDPs as a target for anti-amoebic intervention and identifies quassinoid phytochemical compounds as suitable for optimization into a new therapy against $N$. fowleri.
\end{abstract}

Keywords: Neigleria fowleri; Brain eating amoeba; Primary amoebic meningoencephalitis; Quassinoids, Amoebicidal; Phytotherapy; Molecular docking.

\section{Introduction}

$N$. fowleri is considered as an amphizoic amoeba because of its property to survive in a free-living state as well as in the host. In free living form it is found in water or soil and in the host found in human central nervous system [1]. Life cycle of $N$. fowleri is comprised of three stages, Trophozoites (feeding stage), Flagellate (motility stage) and Cysts (surviving). N. fowleri enters the human body in the trophozoite form which is infectious stage. Food cups are found on the surface of trophozoites through which they ingest bacteria, fungi, and human tissue [2]. N. fowleri passes into the host during recreational activities such as water sports, swimming, cultural practices (use of neti pots) religious practices of Muslims (ablution or "wuzu") and Hindus (bathing in river Ganges) [3]. $N$. fowleri forces itself into the nasal cavity and after passing through olfactory nerve $\mathrm{N}$. fowleri reaches CNS via cribriform plate [2]. This pathogen attacks by releasing cytotoxic molecules in the central nervous system which cause necrosis and lead to primary amoebic meningoencephalitis [4].

PAM was reported for first time in Australia in 1965 although there has been a record of its occurrance as early as 1937 in Virginia, America. Cases have been reported from the America, Australia, Europe and Asia. Rise in temperature is the major factor which contributes to increases PAM infection, as high temperature favours multiplication of the amoeba $[5,6]$. PAM symptoms are fever, nausea, vomiting, severe headache, stiff neck, altered mental status, hallucinations, seizures, and coma [7]. Overall, this disease is extremely rare but deadly; about 235 PAM cases have been reported worldwide till to date. Reports have been of almost always fatal PAM infection, with survival rate of approximately 5\% [8]. In Pakistan alone, 40 deaths have been reported in Karachi 
from 2010 to 2015 [7]. The incubation period for PAM is about 5 to 7 days, and infected individual died within a week [1]. From 1962 to 2014, only three people out of 133 infected with N. fowleri have survived in the USA [6]. Cerebrospinal fluid smear, PCR and CT scan are normally used to diagnose N. fowleri ([7].

Drugs that have been used in the past for treatment of PAM inlcude Amphotericin B, Fluconazole, Azithromycin, Miltefosine and Rifamin. These drugs either alter membrane permeability, inhibit protein synthesis or RNA polymerase activity, with side effects like diarrhoea, nausea, chills, vomiting, malaise, heartburn, drowsiness, dizziness and headache [4]. Owing to lack of any vaccine and side effects of antibiotics against $N$. fowleri [9], improved drugs are required for prevention and treatment of $N$. fowleri infection. For the discovery and development of drugs against selected targets, plethora of computational approaches such as comparative genomics, molecular docking and virtual screening are used. Previously, we reported HSP70 as potential therapeutic candidate against $N$. fowleri [10]. CDPs of $N$. fowleri could also serve as important therapeutic candidates. In this study, anti-amoebic quassinoids from literature were mined and used for molecular docking with CDPs of N. fowleri. Currently, the authors are also involved in screening large library of quassinoids against different amoebic species and their comparison at ortholog and paralog scale.

\section{Method and analysis}

Interest in computational drug discovery has been increasing in the recent era and chemicals scaffolds are being explored by researchers for their therapeutic and pharmacological effects [11] using various computational algorithms and softwares. For computational assisted screening of quassinoids against CDPs of N. fowleri, CDP sequences were downloaded from the Amoeba Genomics Resource Database (http://amoebadb.org/amoeba/). Accession numbers have been mentioned in the Table 1. Phsphorylation potential was obtained from the NetPhos 3.1 server [12]. Interplay of phosphorylation and O- $\beta$-glycosylation i.e. Yin-Yang sites were identified using YinOYang server 2.1 [13]. Molecular weight , theoretical pI and grand average of hydrophobicity (GRAVY) were identified using Expasy tools [14]. TMHMM server [15] was used for assessing the presence of transmembrane helices in the proteins.

Table 1. Different physico-chemical parameters of $N$. fowleri CDPs. Residues in brackets against the third and sixth CDP are the ones showing phosphorylation at residues interacting with quassinoid molecules.

\begin{tabular}{|c|c|c|c|c|c|c|c|c|}
\hline Serial No. & $\begin{array}{l}\text { Accession } \\
\text { no. }\end{array}$ & $\begin{array}{l}\text { No. of } \\
\text { amino } \\
\text { acids } \\
\end{array}$ & $\begin{array}{l}\text { Molecular } \\
\text { weight }\end{array}$ & $\begin{array}{l}\text { Theoretical } \\
\text { pI }\end{array}$ & GRAVY & $\begin{array}{l}\text { Predicted } \\
\text { TMHs }\end{array}$ & $\begin{array}{l}\text { No. of } \\
\text { phosphorylated } \\
\text { residues }\end{array}$ & $\begin{array}{l}\text { No. o } \\
\text { YinOYang } \\
\text { sites }\end{array}$ \\
\hline 1 & NF0026440 & 545 & 60032.69 & 5.23 & -0.579 & 0 & 106 & 25 \\
\hline 2 & NF0036940 & 382 & 45053.14 & 8.64 & -0.188 & 3 & 39 & 3 \\
\hline 3 & NF0045650 & 161 & 19343.08 & 5.60 & -0.635 & 0 & $21(\mathrm{~T} 29, \mathrm{~T} 30)$ & 3 \\
\hline 4 & NF0080760_2 & 258 & 29006.76 & 6.54 & -0.301 & 0 & 31 & 6 \\
\hline 5 & NF0084440_2 & 137 & 15949.08 & 8.90 & 0.803 & 2 & 8 & - \\
\hline 6 & NF0090830 & 398 & 43473.21 & 9.89 & -0.892 & 0 & 79 (T341, S346) & 18 \\
\hline 7 & NF0111200 & 384 & 42852.93 & 7.10 & -0.439 & 0 & 40 & 2 \\
\hline 8 & NF0120690_1 & 106 & 12601.94 & 8.58 & 0.460 & 2 & 8 & - \\
\hline
\end{tabular}

3D structures were predicted using the I-TASSER software suit $[16,17]$ using templates from the RCSB Protein Data Bank. Quassinoid compounds (Table 2) were downloaded from the PubChem database, optimized and stored in a .mdb database. For docking, protein structures were protonated as well as energy minimized until a gradient of 0.05 was attained. Docking was carried out in 
bioRxiv preprint doi: https://doi org/10.1101/367912; this version posted July 14 2018. The copyright holder for this preprint (which was not certified by peer review) is the author/funder, who has granted bioRxiv a license to display the preprint in perpetuity. It is made available under aCC-BY-NC 4.0 International license.

Molecular Operating Environment (MOE) software suite. Parameters for placement: Triangle match and rescoring by London $\mathrm{dG}$ and Affinity dG force respectively. Refinement was done through forcefield method. The best structure with least $S$ value was retained for further downstream analysis. Ligand interactions were visualized in 2D [18].

Table 2. Anti-amoebic quassinoids (Reviewed by [19]), used in this study for docking and analysis against CDPs of N. fowleri.

\begin{tabular}{|c|c|c|c|c|c|}
\hline $\begin{array}{l}\text { Serial } \\
\text { no. }\end{array}$ & Compound & $\begin{array}{l}\text { Plant source of } \\
\text { isolation }\end{array}$ & $\begin{array}{l}\text { IC50 } \\
(\mu \mathrm{g} / \mathrm{ml})\end{array}$ & 2D structure & Reference \\
\hline 1 & Bruceantin & Brucea javanica & 0.019 & & $\begin{array}{l}\text { Wright et al., } \\
1988\end{array}$ \\
\hline 2 & Bruceine A & Brucea javanica & 0.097 & & $\begin{array}{l}\text { Wright et al., } \\
1988\end{array}$ \\
\hline 3 & Bruceine B & Brucea javanica & 0.306 & & $\begin{array}{l}\text { Wright et al., } \\
1988\end{array}$ \\
\hline 4 & Bruceine C & Brucea javanica & 0.297 & & $\begin{array}{l}\text { Wright et al., } \\
1988\end{array}$ \\
\hline 5 & Bruceine D & Brucea javanica & 0.386 & & $\begin{array}{l}\text { Wright et al., } \\
1988\end{array}$ \\
\hline 6 & Brusatol & Brucea javanica & 0.062 & & $\begin{array}{l}\text { Wright et al., } \\
1993\end{array}$ \\
\hline 7 & Ailanthinone & Simarouba amara & 0.063 & & $\begin{array}{l}\text { Wright et al., } \\
1988\end{array}$ \\
\hline 8 & Glaucarubin & Simarouba glauca & 1.57 & & $\begin{array}{l}\text { Gillin et al., } \\
1982\end{array}$ \\
\hline 9 & Glaucarubinone & Simarouba amara & 0.168 & & $\begin{array}{l}\text { Wright et al., } \\
1988\end{array}$ \\
\hline
\end{tabular}




\begin{tabular}{|l|l|l|l|l|l|}
\hline 10 & Glaucarubolone & $\begin{array}{l}\text { Brucea } \\
\text { antidysentrica }\end{array}$ & 0.12 & $\mathrm{Kambu}, 1990$ \\
\hline 11 & Quassin & Quassia amara & 0.5 & Keene et al., \\
\hline
\end{tabular}

\section{Results}

We are constantly in search of new and better drugs for cure against diseases of almost all types. High-throughput screening, structure based interaction and quantitative structure activity relationship is usually used for guiding bioassays. Isolated molecules may then be developed into drugs with improved clinical action or fewer side effects [19]. There is a lot of scope in investigating the nature derived plant compounds and herbal therapies for their safety and efficacy and harnessing their potential against diseases. Several drugs have been tested for $N$. fowleri caused PAM with varying results [20-30].

Quassinoids are phytoconstituents of several Simaroubaceae species and consist of degraded triterpenes. They have demonstrated activity against viral proteins [31, 32] and cancerous cells [33, 34]. They have also shown pharmacological action against inflammation, insects and ulcer [31]. They bind proteins in amoeba and prevent their proliferation. Their impact on protozoan/amoeba has been reviewed in detail elsewhere [19]. In the quest for new, effective, and safe amoebicidal agents against $N$. fowleri, anti-amoebic quassinoid molecule interactions were identified against CDPs of this pathogen. Each CDP was tested against all eight anti-ameobic quassinoids (mentioned in Table 2) and small molecule with the best ability to bind to the specific CDP was analysed for interacting residues.

All CDPs had different sequence and hence, structures. This demonstrates a pattern of paralog existence and extreme variation of CDP sequences in $N$. fowleri. Molecular interaction did not show conservation of a specific binding residue. Despite this variation of sequence and no conservation of binding site, majority i.e. 3 paralogs showed best affinity for Brucein B molecule. Two CDPs showed maximum affinity for Brusatol (Table 3). Phosphorylation pattern also varied for all paralogs. In two CDPs (Accession no: NF0045650 and NF0090830), two phosphorylated residues made interaction with ligand. One had both threonines while other paralog had one serine and one threonine showing interaction with quassinoids Glaucarubin and Bruceine B respectively. No such pattern was observed for other paralogs. YinOYang sites were present in six CDPs (Table 3) but none showed interplay of phosphorylation and glycosylation at docked site residues.

Since, formulation of plant derived small molecules into drugs, entails screening enormous number of plant extracts followed by the compound isolation and identification of action mechanism, this study could prove useful for guiding such assays. Toxicity tests could then be done to establish safety for the host and specificity of action on pathogen. In the present study, docking was attempted to screen potent amoebicidal quassinoid phytochemicals against CDPs of $N$. fowleri. The study is a preliminary information report and experimental assays are further needed to validate the findings. 
bioRxiv preprint doi: https://doi.org/10.1101/367912; this version posted July 14,2018 . The copyright holder for this preprint (which was not certified by peer review) is the author/funder, who has granted bioRxiv a license to display the preprint in perpetuity. It is made available under aCC-BY-NC 4.0 International license.

Table 3. Protein structure and interaction information for the studied CDPs of $N$. fowleri. Serial numbers refer to the accession numbers mentioned against similar serial numbers in Table 1 . $\bigcirc_{\text {depicts polar residue, }}$ acidic, $\mathrm{O}$ basic, $\mathrm{O}$ hydrophobic, side chain acceptor, 4 side chain donor, $m$ acceptor, $\longrightarrow$ backbone donor, 0 ligand exposure, $\bigcirc$ receptor exposure, 00 arene-arene, arene cation and black dotted line as proximity contour.

\begin{tabular}{|c|c|c|c|c|c|}
\hline $\begin{array}{l}\text { Serial } \\
\text { no. }\end{array}$ & $\begin{array}{l}\text { Template } \\
\text { PDB }\end{array}$ & 3D structure & $\begin{array}{l}\text { Best docked } \\
\text { compound }\end{array}$ & $\begin{array}{l}\text { Bindin } \\
\mathrm{g} \\
\text { energy } \\
\text { value }\end{array}$ & 2D interaction of best docked complex \\
\hline 1 & $2 \operatorname{tma}$ & क्ष & Brusatol & -3.9002 & (10) \\
\hline 2 & 4 ry 2 & sorsore & $\begin{array}{l}\text { Glaucarubinon } \\
\text { e }\end{array}$ & -6.1092 & (a) \\
\hline 3 & $3 \mathrm{kkc}$ & & Glaucarubin & -3.7145 & (ii) \\
\hline 4 & $3 b 5 x$ & & Bruceine B & -6.2030 & 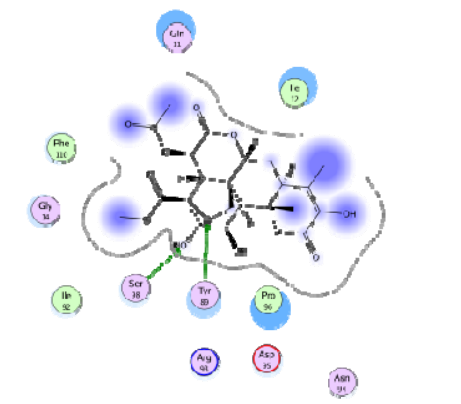 \\
\hline
\end{tabular}




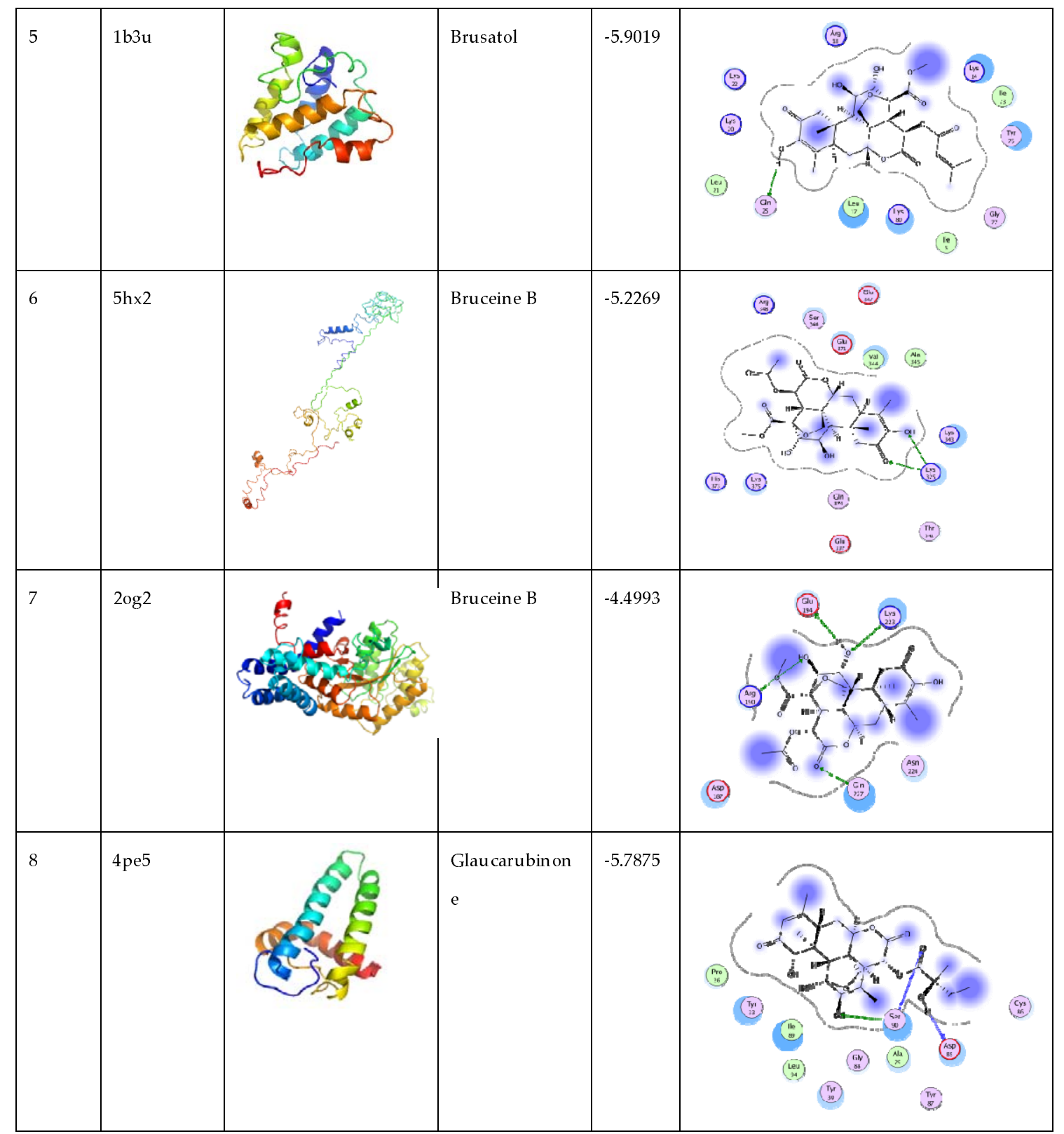

Supplementary Materials: The predicted 3D protein structure coordinates of cell division proteins (Serial no. $1-8$, Table 1) can be requested from the corresponding author.

Acknowledgments: The authors are thankful to Alexandra Elbakyan for literature support. This work did not receive any particular funding.

Author Contributions: “Z.B. and A.Y. conceived and designed the experiments; Z.B. performed the experiments; Z.B. analyzed the data; Z.B. and S.Z. wrote the original draft of the paper; AY edited and checked the final version of paper."

Conflicts of Interest: "The authors declare no conflict of interest."

\section{References}

1. Abrahams-Sandi, E.; Retana-Moreira, L.; Castro-Castillo, A.; Reyes-Batlle, M.; Lorenzo-Morales J. Fatal meningoencephalitis in child and isolation of Naegleria fowleri from hot springs in Costa Rica. Emerg Infect Dis 2015, 21, 382 . 
2. De Jonckheere, J. F. Origin and evolution of the worldwide distributed pathogenic amoeboflagellate Naegleria fowleri. Infect Genet Evol 2011, 11, 1520-1528.

3. Siddiqui, R.; Khan, N. A. Primary amoebic meningoencephalitis caused by Naegleria fowleri: an old enemy presenting new challenges. PLoS Negl Trop Dis 2014, 8, e3017.

4. Pugh, J. J.; Levy, R. A. Naegleria fowleri: Diagnosis, Pathophysiology of Brain Inflammation, and Antimicrobial Treatments. ACS Chem Neurosci 2016, 7, 1178-1179.

5. Martinez, A. J.; Visvesvara, G. S. Free-living, amphizoic and opportunistic amebas. Brain Pathol 1997, 7(1), 583-598.

6. Mukhtar, F.; Wazir, M. S. Naeglaria fowleri: The brain eating amoeba or an enigma?. J Ayub Med Coll Abbottabad 2015, 27, 735-736.

7. Abbas, S. S.; Naveed, S.; Qamar, F.; Ali, Z. B. Enlightenment on Naegleria fowleri; a brain eating amoeba-an alarming call. Int Edu Res J 2015 1, 1-3.

8. Panda, A.; Khalil, S.; Mirdha, B. R.; Singh, Y.; Kaushik, S. Prevalence of Naegleria fowleri in environmental samples from northern part of India. PloS one 2015, 10, e0137736.

9. Khan, M. M.; Ahmad, I. Naegleria:Preventable by water chlorination. Gomal J Med Sci 2015, 13(2).

10. Basharat, Z.; Zaib, S.; Yasmin, A. Computational study of some amoebicidal phytochemicals against heat shock protein of Naegleria fowleri. Gene Rep 2017a, 6, 158-162.

11. Moreno, S.; Galván, E. M.; Vázquez, N.; Fiorilli, G.; Guido, P. C. Antibacterial efficacy of Rosmarinus officinalis phy tochemicals against nosocomial multidrug-resistant bacteria grown in planktonic culture and biofilm. In The Battle Against Microbial Pathogens: Basic Science, Technological Advances and Educational Programs, 1st ed.; Formatex: Badajoz, Spain, 2015; pp. 3-8.

12. Blom, N.; Sicheritz-Ponten, T.; Gupta, R.; Gammeltoft, S.; Brunak, S. Prediction of post-translational glycosylation and phosphorylation of proteins from the amino acid sequence. Proteomics 2004, 4 , 1633-49.

13. Gupta, R.; S. Brunak. Prediction of glycosylation across the human proteome and the correlation to protein function. In Pac Symp Biocomput, 2002, 7, 310-322.

14. Wilkins, M.R.; Gasteiger, E.; Bairoch, A.; Sanchez, J.C.; Williams, K.L.; Appel, R.D.; Hochstrasser, D.F. Protein identification and analysis tools in the ExPASy server. Methods Mol Biol, 1999, 112, 531-52.

15. Sonnhammer, E.L.; von Heijne, G.; Krogh, A.A. hidden Markov model for predicting transmembrane helices in protein sequences. Proc Int Conf Intell Syst Mol Biol, 1998. 6, 175-182.

16. Zhang, Y. I-TASSER server for protein 3D structure prediction. BMC Bioinformatics 2008, 9, 40.

17. Roy, A.; Kucukural, A.; Zhang, Y. I-TASSER: a unified platform for automated protein structure and function prediction. Nat Protoc 2010 5, 725-738.

18. Basharat, Z.; Yasmin, A. Energy landscape of a GSTP1 polymorph linked with cytological function decay in response to chemical stressors. Gene 2017, 609, 19-27.

19. Singh, S.; Bharti, N.; Mohapatra, P. P. Chemistry and biology of synthetic and naturally occurring antiamoebic agents. Chem Rev 2009 109, 1900-1947.

20. Seidel, J. S.; Harmatz, P.; Visvesvara, G. S.; Cohen, A.; Edwards, J.; Turner, J. Successful treatment of primary amebic meningoencephalitis. New England JMed 1982, 306, 346-348.

21. Schuster, F. L.; Guglielmo, B. J.; Visvesvara, G. S. In-vitro activity of miltefosine and voriconazole on clinical isolates of free-living amebas: Balamuthia mandrillaris, Acanthamoeba spp., and Naegleria fowleri.J Eukaryotic Microbiol 2006, 53, 121-126. 
22. Goswick, S. M.; Brenner, G. M. Activities of azithromycin and amphotericin B against Naegleria fowleri in vitro and in a mouse model of primary amebic meningoencephalitis. Antimicrob Agents Chemother $200347,524-528$.

23. Soltow, S. M.; Brenner, G. M. Synergistic activities of azithromycin and amphotericin B against Naegleria fowleri in vitro and in a mouse model of primary amebic meningoencephalitis. Antimicrob Agents Chemother 2007, 51, 23-27.

24. Cope, J. R.; Conrad, D. A.; Cohen, N.; Cotilla, M.; DaSilva, A.; Jackson, J.; Visvesvara, G. S. Use of the novel therapeutic agent miltefosine for the treatment of primary amebic meningoencephalitis: report of 1 fatal and 1 surviving case. Clin Infect Dis 2016 62, 774-776.

25. Heggie, T. W.; Küpper, T. Surviving Naegleria fowleri infections: A successful case report and novel therapeutic approach. Travel Med Infect Dis 2016 (In press) DOI: 10.1016/j.tmaid.2016.12.005.

26. Baig, A. M.; Khan, N. A. Novel chemotherapeutic strategies in the management of primary amoebic meningoencephalitis due to Naegleria fowleri. CNS Neurosci Therap, 2004, 20, 289-290.

27. Baig, A. M.; Kulsoom, H.; Khan, N. A. Primary amoebic meningoencephalitis: amoebicidal effects of clinically approved drugs against Naegleria fowleri. J Med Microbiol 2014, 63, 760-762.

28. Capewell, L.G.; Harris, A.M.; Yoder, J.S.; Cope, J.R.; Eddy, B.A.; Roy, S.L.; Visvesvara, G.S.; Fox, L.M.; Beach, M.J. Diagnosis, clinical course, and treatment of primary amoebic meningoencephalitis in the United States, 1937-2013. J Pediatric Infect Dis Soc 2014, p.piu103.

29. Linam, W.M.; Ahmed, M.; Cope, J.R.; Chu, C.; Visvesvara, G.S.; da Silva, A.J.; Qvarnstrom, Y.; Green, J. Successful treatment of an adolescent with Naegleria fowleri primary amebic meningoencephalitis. Pediatrics 2015, 135, e744-e748.

30. Rice, C. A.; Colon, B. L.; Alp, M.; Göker, H.; Boykin, D. W.; Kyle, D. E. Bis-benzimidazole hits against Naegleria fowleri discovered with new high-throughput screens. Antimicrob Agents Chemother 201559 , 2037-2044.

31. Win, N.N.; Ito, T.; Win, Y.Y.; Ngwe, H.; Kodama, T.; Abe, I.; Morita, H. Quassinoids: Viral protein R inhibitors from Picrasma javanica bark collected in Myanmar for HIV infection. Bioorganic Med Chem Lett 2016, 26, 4620-4624.

32. Ryu, S.M.; Kwon, J.; Seo, Y.H.; Song, E.G.; Hong, S.S.; Kim, B.S.; Hong, J.S.; Ryu, K.H.; Lee, D. Quassinoids isolated from Brucea javanica inhibit pepper mottle virus in pepper. Virus Res 2017, 227, 49-56.

33. Jiwajinda, S.; Santisopasri, V.; Murakami, A.; Kawanaka, M.; Kawanaka, H.; Gasquet, M.; Eilas, R.; Balansard, G.; Ohigashi, H. In vitro anti-tumor promoting and anti-parasitic activities of the quassinoids from Eurycoma longifolia, a medicinal plant in Southeast Asia. J Ethnopharmacol 2002 82, $55-58$.

34. Tong, K.L.; Chan, K.L.; AbuBakar, S.; Low, B.S.; Ma, H.Q.; Wong, P. F. The in vitro and in vivo anti-cancer activities of a standardized quassinoids composition from eurycoma longifolia on lncap human prostate cancer cells. PloS one 2015, 10, e0121752. 